\title{
Ecumenical reflections on the undeniable influence of the Reformation on the South African society
}

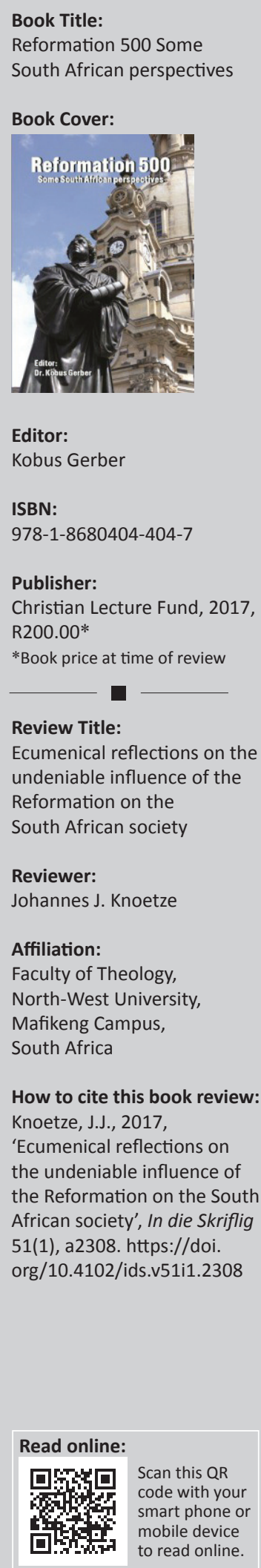

In 2017 the courageous attempts of Martin Luther to reform the church from within are celebrated all over the world, not only by the Lutheran Church, but also in many ecumenical bodies. This publication deals specifically with the influence and importance of the Reformation within the South African society. The editor Dr Kobus Gerber, is a well-known actor in ecumenical circles in South Africa and abroad. In the 'Foreword' it is stated that the Conventus of the Churches of the Reformation in Southern Africa invited authors from different denominations to describe any aspect of the Reformation from their own, or their denomination's perspective.

The idea was to create a mosaic or kaleidoscope which can stimulate further reflection in an ecumenical context where we start to share our experiences and not debate our doctrinal differences and issues. (p. 5)

The thirteen articles from twelve different denominations will indeed contribute to further conversation on our South African society and ecumenical relations.

The articles are academically well founded. Each with its own focus on the influence of the Reformation in the praxis of theology or society in general. Although most of the articles are written from the perspective of the reformed church family, there are also important contributions from denominations outside the reformed tradition such as the Zion Christian Church (ZCC), the Apostolic Faith Mission (AFM) and the Roman Catholic Church (RCC). According to the reviewer, three main themes that influence the South African society can be identified, namely education, the relationship between church and state, and ecumenism.

Chapters 1 (Free reformed churches), 4 (ZCC) and 12 (Dutch Reformed Church) focus on the role of the Reformation in the education of children and young people in general within the South African context. Chapter 1 indicates how the reformed education developed into private education in South Africa in the twenty-first century. In Chapter 4 the importance and influence of reformed theological education within the initial leadership of the ZCC is emphasised. 'Unfortunately, the ZCC has lost its theological direction in the midst of African religion' (p. 61). A good historical view is given in Chapter 12 on how Luther and Calvin regarded education as important to their specific contexts with application to the South African context. It emphasises 'that all children should have equal educational opportunity regardless of birth or wealth' (p. 175).

The relationship between church and state is described from different points of view to indicate how the principles of the Reformation influenced the relationship between the church and the state. In Chapter 2 (Netherdutch Reformed Church of Africa - NHKA) the challenge to be continuously reformed through the Word and the Spirit is discussed. This is done from the reformational perspective of the NHKA. The historical development of the Peoples Church of Africa as a reformed church is described in Chapter 3. The core insight of the Protestant Reformation is described by Nurnberger in Chapter 7 (Lutheran Church) as the fact that 'we are righteous and sinners at the same time (simul iustus et peccator)' (p. 93). This understanding is spelled out in nine implications for the economic and ecological impasses we are currently facing. Chapter 8 (Dutch Reformed Church in Africa) gives attention to leadership and six societal challenges to the church in relation to the state. In Chapter 13 (Reformed Churches in South Africa) the role of Calvinism in the development and the contesting of apartheid is described.

Ecumenism is described in Chapter 5 (Evangelical Lutheran Church in Southern Africa), 6 (Apostolic Faith Mission), 9 (Uniting Presbyterian Church in Southern Africa), 10 (Roman

Copyright: @ 2017. The Authors. Licensee: AOSIS. This work is licensed under the Creative Commons Attribution License. 
Catholic Church), and 11 (Baptist Union of South Africa). In Chapter 5 the reader is warned against the fallacy of 'pure doctrine' and how the distinction between fixed and focused theology ( $p$. 72) can help in this regard. The relationship and distinction between Reformation and the Pentecostal movement are discussed in Chapter 6. In Chapter 9 some reasons why the World Communion of Reformed Churches are joining in celebrating the Luther Reformation are described as 'with the hope and prayer for Christian unity, a renewed commitment to mission, justice and ecumenical engagement' (p. 145). Chapter 10 discusses the document Declaration on the way: Church, ministry and eucharist, drawn and published in 2015 through the United States Catholic Conference of Bishops (USCCB) and the Evangelical Lutheran Church in America (ELCA). The basic principles of the Reformation (sola's) are discussed from a Baptist point of view in Chapter 11.

This is indeed an ecumenical book with a definite contribution to the South African society from a Reformed perspective. It can be recommended for pastors, politicians and the church people in general. 